\title{
SHA, Heila. 2017. Care and Ageing in North-West China. Berlin: Lit Verlag
}

Book reviews

\section{Justine Rochot}

Translator. N. Jayaram

\section{(2) OpenEdition}

\section{Journals}

Electronic version

URL: http://journals.openedition.org/chinaperspectives/8586

DOI: 10.4000/chinaperspectives.8586

ISSN: 1996-4617

\section{Publisher}

Centre d'étude français sur la Chine contemporaine

Printed version

Date of publication: 31 December 2018

ISSN: 2070-3449

\section{Electronic reference}

Justine Rochot, «SHA, Heila. 2017. Care and Ageing in North-West China. Berlin: Lit Verlag », China Perspectives [Online], 2018-4 | 2018, Online since 12 February 2019, connection on 24 September 2020. URL : http://journals.openedition.org/chinaperspectives/8586 ; DOI : https://doi.org/10.4000/ chinaperspectives.8586

This text was automatically generated on 24 September 2020

(c) All rights reserved 


\section{SHA, Heila. 2017. Care and Ageing in North-West China. Berlin: Lit Verlag}

Book reviews

\section{Justine Rochot}

Translation : N. Jayaram

In examining the experiences of

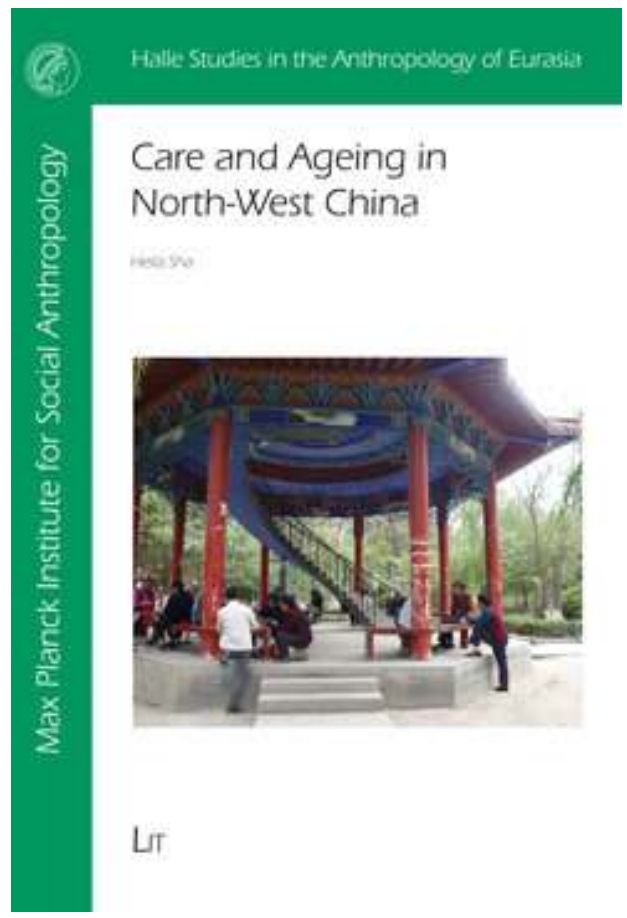

ageing in Tuan 143 of the bingtuan ${ }^{1}$ 兵团 in Xinjiang, this first work by ethnic Kazakh anthropologist Heila Sha (Saheira Haliel), who hails from the region, offers valuable ethnographic insights into two fields of research too often devoid of them. On the one hand, she has enriched current studies on ageing in China by shifting attention to a region little 
examined from this perspective, and moreover to the bingtuan, a space characterised by the ageing of its population, and uniquely combining both urban and rural features as well as specific management style and social identities. The notion of care, stemming from studies combining attention to material practices (care for) and emotional work around looking after others (care about), informs the book but could have benefited from clearer definition. However, the book stands out by stressing the gendered, emotional, and intergenerational dimensions of care, often neglected in work on ageing in China (pp. 18-23). On the other hand, by being attentive to practices and lifestyles of the elderly currently living in the bingtuan, the author offers greater insights on daily and family life and on the state's concrete work in these former agro-military colonies thus far mostly analysed through the prism of their migratory history and institutional transformations. This recent addition to China literature in English is especially welcome given the tightening of research conditions in Xinjiang, all the more so as the bingtuan is a far from easy space to carry out ethnographic work.

2 This monograph, reworked from a thesis defended in 2015, resulted from fieldwork carried out between 2012 and 2013 in Tuan 143, located near Shihezi City and housing about 60,000 people. The author lived among the elderly in two liandui 连队 (agriculture production villages) and in Huayan Town, locally called tuanbu 团部 (regimental headquarters). Heila Sha gathered extremely rich data based not only on her daily life experience among families, but also on participant-observations in public places or in "elderly clubs," questionnaires, life stories of elderly and their kin, as well as on her volunteering at the district community office and justice office.

3 Relying on a theoretical framework borrowed from the anthropology of ageing, care, and social security, the author seeks to show that "the 'ultimate collapse' of filial piety predicted by so many studies of rural settings has not materialized [in the bingtuan]" (p. 14). Family relations and obligations that individuals are subject to undergo constant negotiations and accommodations according to each person's situation: care practices must thus be understood dynamically as the intersection of a complex network of actors - individuals, their families, the market, and the state (p. 262). The recent emergence of negotiated generational interdependence is partly the fruit of an individualisation process among the elderly themselves. This last point perhaps constitutes the book's most original contribution. The author says: "Due to the pension system and other benefits, the majority of bingtuan elderly have established a new independent lifestyle and developed strategies to cope with uncertainties that arise in old age" (p. 4). While sociologist Zhang Hong called for more studies on peer-ageing strategies of China's elderly back in 2009 (Zhang 2009), very little work has resulted until now: attention paid in this book to the elderly as veritable actors in their ageing process in uncertain contexts is a commendable contribution to literature on ageing in China. 
The book is structured in eight chapters. Chapters 1 to 3 lay the work's general context. After developing the theoretical framework and ethnographic conditions (Chapter 1), Chapter 2 broadly traces Xinjiang's and the bingtuan's general history and the evolution of its administration, economy, and population following migratory waves. Chapter 3 plunges straight into the history of Tuan 143 and its elderly. The chapter offers a good intersectional reading of inequalities affecting their lives and now influencing individuals' ageing, according to their gender, generation, provincial origin, ${ }^{2}$ and professional status: laojiu (former Kuomintang soldiers and the bingtuan's first recruits, who currently get the highest pensions and social assistance), zhigong 职工 (the biggest group, including men and women from different migratory waves, whether or not state-organised, now all receiving pensions), and wuqigong 五七工 (a precarious category of mostly women long denied pensions until 2010, when the right was granted following petition movements). Individuals' actual ageing experiences also depend on their residence sites, distinguishing those still in depopulated agricultural units, lacking health-care, and badly connected by transport, from the rising numbers of those benefiting from urbanisation policies launched since 2010 and able to live in the Tuan, with its hospitals, recreation spaces, modern buildings (loufang 楼房), and shops.

5 Chapters 4 and 5 deal with elderly people's two concerns: health and housing. In a context of uncertainty regarding the quality and cost of care, and afraid of becoming burdens on their families, the elderly in fact engage in many self-care practices, including regular attention to food, physical exercise to keep fit, occasional participation in odd jobs, and a fervour for overpriced healthcare products (baojianpin 保健品) marketed in the Tuan by private firms backed by the local government. Chapter 5 , dealing with personal and family strategies adopted by the aged to move to the Tuan, examines the influence of urbanisation and housing privatisation policies on the redefinition and spatial visibilization of hierarchies structuring the elderly group.

6 Chapters 6 to 8 focus on intimacy, family, and care relations built by individuals in the domestic sphere. Chapter 6, devoted to intergenerational relations, shows how people turn out to be both conservative and pragmatic (p. 167). While the elderly increasingly value living alone, family budgets and housing constraints have pushed them towards "reshaped patterns of inter-generational reciprocity through coresidence and childcare" (p. 199). Gender expectations of care have also been transformed: boys certainly receive greater attention from their aged parents, but girls are also more valued for their emotional presence and support for their parents rather than for their in-laws. Chapter 7, focusing on the elderly needing long-term care, shows that the family continues to play a central role in an insufficient institutional context. While spouses are still often the main caregivers of the elderly, the ways children take charge can assume diverse and sometimes original forms: care may be assigned to a retired son or daughter, to a 
still active sibling funded by others for his work, or to all children taking turns to look after their parents. The last chapter, on remarriages and cohabitations among the elderly, touches on a rarely examined facet in an ethnographic perspective: it shows the extent to which such pairings make up for geographical distancing of children by stressing the two parties' mutual support. These couples also betray structural inequalities: the generally older men enjoy higher pensions and an apartment, and they want care and value cohabitation; the women are much younger, often pensionless, and seek a relationship with an economically stable partner secured by a marriage certificate inequalities that can generate much tension among couples and with children.

7 While the book is a very good introduction to problematics linked to ageing and care in the bingtuan, it also raises many questions as regards the challenges of ageing in China. It is perhaps regrettable that the author did not define and deconstruct at the outset the very categories of the aged: her choice at times to focus on "those aged over 60" ( $p$. 85), respecting the usual but contestable statistical thresholds, may prevent her from defining the multiplicity of ways and biographical points that could define the elderly in China now (attained retirement? grandparenthood? the symbolic age of 60? lost autonomy?) as well as the role played by state policies and gendered approaches in the construction of these affiliations. For women especially, the early retirement age in the bingtuan (at 50, the author says, p. 77) and the importance of the grandmotherly care function could be expected to justify ignoring the arbitrary 60 threshold: such a perspective would have made it possible to explicitly touch on other issues specific to this younger generation, which is not limited to the sole status of care providers and is itself the subject of specific problematics related both to their life course and to their political socialisations. It would also have been good to know to what extent family planning policies were applied in the bingtuan, a perspective the author has ignored: how have they transformed family and social relations, care practices, and the future prospects of the youngest fringe of those studied? How do such courses model individualisation processes that may be more generationally located?

8 These categories, lacking deconstruction, trip up the author throughout the book: she finds herself curtailing a stay among people "only in their fifties" on the pretext of wanting to live "with older people" (p. 24), while spending much time in "elderly clubs" described as being frequented by several "middle-aged ladies" (p. 27) - without revealing what concrete experiences relate to this category. It would have been good if the "clubs" and public places the author frequented were described in greater detail, the study of such spaces having perhaps helped contrast them with the home and family spaces and more finely supported the thesis of "active ageing and individualisation of the aged" described in the conclusion as the main result of the study (p. 262). 


\section{BIBLIOGRAPHY}

ZHANG, Hong. 2009. "The New Realities of Aging in Contemporary China: Coping with the Decline in Family Care." In Jay Sokolovsky (ed.). The Cultural Context of Aging: Worldwide Perspectives.

Westport: Praeger, 2009: 196-215.

\section{NOTES}

1. The bingtuan, or "Xinjiang Production and Construction Corps," is defined by the author as a "paramilitary state organisation": "Its population is comprised largely of ethnic Han migrants who came to Xinjiang, mostly through state-organized migration programmes, in several waves since the 1949 Communist Revolution" (p. 1).

2. In the author's view, both ethnicity and religion are factors that matter, the Tuan being mostly composed of Han (including many aged widows who converted to Christianity) but also Kazakhs and Hui. Unfortunately, this aspect is sparsely dealt with in the book, given the issue's political sensitiveness.

\section{AUTHORS}

\section{JUSTINE ROCHOT}

Justine Rochot is a doctoral candidate with Centre for Studies on Modern and Contemporary China (CECMC) at EHESS (School for Advanced Studies in the Social Sciences), and with Institute of Economic and Social Development Studies (IEDES) at Université Paris 1 PanthéonSorbonne.jrochot@ehess.fr 